University of Nebraska - Lincoln

DigitalCommons@University of Nebraska - Lincoln

10-1995

\title{
Path to Extinction: Impact of Vegetational Change on Lizard Populations on Arapaho Prairie in the Nebraska Sandhills
}

Royce E. Ballinger

University of Nebraska - Lincoln

Kristin S. Watts

University of Nebraska - Lincoln

Follow this and additional works at: https://digitalcommons.unl.edu/biosciherpetology

Part of the Biodiversity Commons, and the Zoology Commons

Ballinger, Royce E. and Watts, Kristin S., "Path to Extinction: Impact of Vegetational Change on Lizard Populations on Arapaho Prairie in the Nebraska Sandhills" (1995). Papers in Herpetology. 5. https://digitalcommons.unl.edu/biosciherpetology/5

This Article is brought to you for free and open access by the Papers in the Biological Sciences at DigitalCommons@University of Nebraska - Lincoln. It has been accepted for inclusion in Papers in Herpetology by an authorized administrator of DigitalCommons@University of Nebraska - Lincoln. 


\title{
Path to Extinction: Impact of Vegetational Change on Lizard Populations on Arapaho Prairie in the Nebraska Sandhills
}

\begin{abstract}
Since removal of cattle from Arapaho Prairie in 1977, secondary succession has resulted in increased vegetation cover. Studies of resident lizards on a $150 \times 150 \mathrm{~m}$ grid revealed: (1) one lizard species (Holbrookia maculata) has essentially been eliminated in 15 yr (from a maximum of 74 residents in 1979 to three residents in 1993); (2) a second lizard population (Sceloporus undulatus) has declined from 56 residents in 1979 to less than 30 residents in 1993; and (3) preferred microhabitats occupied by lizards have not changed, but their microgeographic distributions have shifted to areas of blowouts, and home ranges have decreased.
\end{abstract}

\section{INTRODUCTION}

Extinction is receiving increasingly frequent field study in recent years, ranging from global scales (Whitcomb et al., 1981; Blaustein and Wake, 1990) to theoretical prediction methods (Foley, 1994). Knowledge of extinction rates are critically important to theories of island biogeography (MacArthur and Wilson, 1967) and community structure (Levins, 1970). Studies often involve endangered species and critically threatened habitats (e.g., Frissell, 1993) or specific species whose ecological abundance has declined noticeably (e.g., Carey, 1993). Extinction also occurs in local populations, especially at the edge of species ranges, for a wide variety of reasons (Terborgh and Winter, 1980). We have documented the decline of two wide-ranging lizard species (Sceloporus undulatus and Holbrookia maculata) in the Sandhills region of Nebraska. These species are abundant and conspicuous members of the herpetofauna in the sandhills in open microhabitats such as blowouts and areas of sparse grass. Our studies indicate that under prevailing conditions of prairie management that do not include factors (i.e., fire and wind erosion) promoting habitat disturbance, these two species will become locally extinct.

The sandhills prairie of W-central Nebraska (Bleed and Flowerday, 1989) is dominated by a mixture of grasses and forbs, including species adapted to survival in the easily disturbed substrate (Weaver, 1965). In prehistoric times, the Nebraska Sandhills were disturbed by bison and weather erosion following periodic fires. Fire is especially important in maintaining the disturbance-adapted, prairie grass system and is estimated to have occurred at irregular intervals of a few years in prehistoric times (Bragg, 1978). Erosion by wind or rain, especially following fires, resulted in open blowouts and washout areas. These disturbances lead to the dominance of specific plant communities, such as sand-binding plants, adapted to accommodate the sandy substrate, but they also produced a mosaic habitat that included open areas needed for animals such as certain grasshoppers (Joern, 1982) and lizards (Ballinger and Jones, 1985).

Ballinger and Jones (1985) reported dramatic effects on two lizard species following a period of low disturbance on Arapaho Prairie in the western Nebraska Sandhills. They found that lizard populations declined following reduced vegetational disturbance that resulted in a denser community of grasses on the prairie. The purpose of this study is to examine whether the continued changes in vegetation over the past $10 \mathrm{yr}$ on Arapaho Prairie have had a continuing effect on the lizard populations.

\section{Methods AND MATERIALS}

The study area was on Arapaho Prairie, Arthur County, Nebraska (sec. 31, 32 T18N R39W). This is a controlled access research site owned by The Nature Conservancy and maintained by the School of Biological Sciences of the University of Nebraska-Lincoln. A description of the area, including a survey of the vegetation, was published by Keeler et al. (1980). Before use of the site by the University in 1977, the land was used for summer cattle grazing. Following removal of cattle in December 1976, secondary succession has resulted in a gradual increase in vegetation density. Local tradition (Miller, 1989), in this vast grassland that predominately supports cattle ranching, prevents use of fire as a management strategy for the prairie, and minimal proactive management activities beyond grazing and/or cutting grass and removing the subsequent hay in the lowland areas have occurred.

Data on lizard populations were obtained on the same $150 \times 150 \mathrm{~m}$ grid used by Ballinger and Jones (1985). The study grid is on the upland slope of a large dune in the center of the two-section Arapaho Prairie. The general vegetation is defined as a sand range site (Stubbendieck, 1989) characterized by 

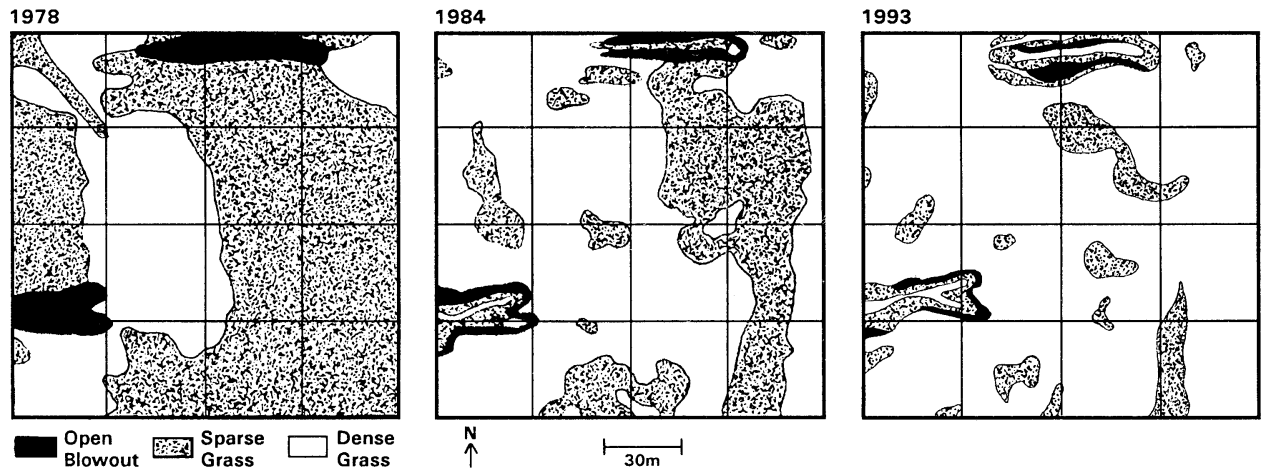

Fig. 1.-Comparison of vegetative cover on the $150 \times 150 \mathrm{~m}$ lizard recapture grid in 1978, 1984 and 1993 on Arapaho Prairie, Arthur County, Nebraska. Cover classes described in text

deep, excessively drained soil. A map in Keeler et. al. (1980) gives specific location of the lizard study grid. Vegetation was characterized using the Daubenmire Square method (Daubenmire, 1959). Ground cover was categorized as open blowout (areas with less than $10 \%$ ground cover), sparse grass (less than $50 \%$ ground cover) and dense grass (more than $50 \%$ ground cover). Yucca plants, the most abundant, woody vegetation, were widely distributed throughout all of these types and frequently served as perch sites for Sceloporus.

We walked the grid systematically (N-S and E-W between grid stakes set $30 \mathrm{~m}$ apart from 6 June to 12 August 1993, 3-5 times per week at various times of the day in order to capture lizards during all phases of their activity. Approximately $103 \mathrm{~h}$ were spent between 0800 and 1200 , and $80 \mathrm{~h}$ between 1200 and $1900 \mathrm{~h}$. Each lizard captured was permanently identified using standard toe clipping techniques (Tinkle, 1967). Individual data recorded included time captured, location of capture and vegetation type. Location of each capture was measured to the nearest $0.1 \mathrm{~m}$ from the place of initial sighting to the nearest permanent grid stake. The resident population was defined as those lizards having the center of their home ranges (determined by the minimum polygon method) within the grid or those captured two or more times during the 3-mo period. Individuals captured only once within the grid were considered potential residents.

\section{RESUlTS AND DisCUSSION}

Estimates of vegetation cover on the mark-recapture grid indicated a continued increase since it was last measured in 1983 (Fig. 1). Vegetation cover was least in 1978 shortly after removal of cattle, and successional changes since then have resulted in a greater proportion of dense grass (Keeler et al., 1980). This was also seen in the reduction of two large blowout/washout areas that were bare sand in 1978.

Three species of lizards (Sceloporus undulatus garmani, Holbrookia maculata and Cnemidophorus sexlineatus) were observed on the mark-recapture grid in 1993. A fourth, rarer species, Eumeces multivirgatus, previously found on Arapaho Prairie (Ballinger et al., 1979), was not observed but may have simply escaped our attention. Quantitative data were obtained only on the northern prairie lizard (Sceloporus) and the lesser earless lizard (Holbrookia), but the latter species was extremely rare.

Only three resident individual Holbrookia (two males, one female) were captured during the summer of 1993. This number is dramatically less than the resident population of 31 Holbrookia $10 \mathrm{yr}$ ago. Total captures (8) of Holbrookia were so low that we are uncertain about the reliability of our population estimate for this species. Nevertheless, it is clear that the Holbrookia population has declined dramatically over the past 15 yr. Previous years' estimates of resident Holbrookia were much higher (68 in 1978, 74 in 1979, 73 in 1980, 70 in 1981, 54 in 1982, 31 in 1983) compared to three in 1993. All three Holbrookia were found in areas well within the grid boundaries and no captures were made along the periphery of the grid where residence status would be uncertain. 
We captured 21 resident Sceloporus undulatus (six male, 15 female) within the mark-recapture grid. Because of the skewed sex ratio, not previously observed, we carefully examined location records of 13 additional Sceloporus captured only once. Four of these were caught just outside, or on the grid margin and were likely nonresidents. Three were captured well within the grid boundaries (one was injured upon capture and thus likely died before being captured again) and were probable residents. Six were captured once within 5-10 $\mathrm{m}$ of the $\mathrm{N}$ boundary in a blowout area. This area contained a number of Sceloporus, some of which were recaptured up to two dozen times. Although it is impossible to be certain of the resident status of these six, a conservative estimate allowing these additional nine individuals (captured once) to be part of the resident population (some could have died during the summer before being recaptured) would yield a total population of 30 individuals. The sexes of these additional nine lizards included six males and three females, bringing the sex ratio to 12 males and 18 females which more closely approximates ratios previously observed (Ballinger and Jones, 1985). Even the conservative estimate of 30 resident Sceloporus is $25 \%$ less than the 40 residents in 1983. Using the less conservative estimate of 21 residents would suggest a decline approaching $50 \%$ in the past 10 yr. Since 1978, the resident adult population of Sceloporus on the mark-recapture grid has declined gradually from a high of 56 in 1979 (and 1980; 50 in 1978) to 50 (1981), 43 (1982), 40 (1983) and 30 (or below) in 1993.

Distribution of the observed microhabitats in which Sceloporus occurred on the grid in 1993 approximated that found previously (Ballinger and Jones, 1985; Ballinger et al., 1990). In 1993, 80 observations (62\%) were of lizards on Yucca substrates, 30 (23\%) were in open sandy areas, $17(13 \%)$ were in sparse grass and only three $(2 \%)$ were in dense grass. Microhabitat data in previous years (1979-1983) for these same substrates were 62-68\% (Yucca,) 21-28\% (open sand), 2-14\% (sparse grass) and 2-7\% (dense grass) (Ballinger and Jones, 1985; Ballinger et al., 1990). Furthermore, distribution of recapture sites was markedly associated with the blowout areas, and areas of activity may have been more restricted than seen previously. Jones and Droge (1980) estimated home ranges of both Sceloporus and Holbrookia on this grid in 1978. We did not capture sufficient Holbrookia to estimate home range size, but we did estimate home range size on 13 individual Sceloporus (10 females and three males). The sample was insufficient to treat males and females separately but the number of recaptures $(\overline{\mathrm{x}}=16 ; 3-23)$ on which the home range estimates were based compared well with Jones and Droge (1980). However, the home ranges in 1993 were significantly smaller $(P<0.05)$ than those estimated by Jones and Droge for 1978. Using identical procedures of Jennrich and Turner (1969) to adjust home range estimates for number of captures, lizards in 1993 had adjusted home ranges of $399.9 \mathrm{~m}^{2}( \pm 244.12 \mathrm{SE}, \mathrm{n}=13$ ) compared to 717.2 (males) and 851.5 (females) reported by Jones and Droge (1980).

The decline in size of resident populations of two lizard species since 1983 follows the trend previously observed that began in 1978 (Ballinger and Jones, 1985). This decline occurred as the vegetation density has gradually increased since removal of cattle from the Prairie. This pattern of vegetation increase is well-recognized by local land use traditions affected by management of grazing cattle (Stubbendieck, 1989). According to range management specialists, the sandhills region of Nebraska has experienced an improved range condition (i.e., denser vegetation cover of grasses) in recent times as a result of improved cattle grazing management (Stubbendieck, 1989). Before modern grazing practices, the sandhills was variously vegetated dependent upon the size of cattle herds, and, presumably in prehistoric times, the size and distribution of native bison herds (Miller, 1989).

The sandy substrate of the region makes the grassland ecosystem it supports vulnerable to disturbance. Combinations of trampling by native grazers and the occurrence of fire in pre-settlement times produced a disturbance-adapted suite of plants and animals able to exploit the areas of open sands that periodically occurred as a result of disturbance (Bragg, 1978). Examples of such disturbanceadapted organisms include a number of sand-binding grasses and forbs (Kaul, 1989) as well as animals such as lizards. One forb, Hayden's penstemon (Penstemon haydeni), which is restricted to open blowout areas, is a declared endangered plant of the region as a result of the reduction in suitable habitat. Recent efforts to monitor and increase the size of populations of Hayden's penstemon have succeeded in bringing it back from the brink of extinction.

Lizard populations such as we observed at Arapaho Prairie could potentially undergo a similar fate 
in areas where disturbance of the substrate is reduced and vegetative cover is allowed to increase to high densities. In such an instance at Arapaho Prairie, populations of two lizard species have declined dramatically. One species, Holbrookia maculata, has almost disappeared from the $150 \times 150 \mathrm{~m}$ study grid, where it was abundant $15 \mathrm{yr}$ ago. The second species, Sceloporus undulatus, has experienced a significant drop (>25\%) in population size in the past $10 \mathrm{yr}$. If this trend continues, local extirpation of these lizards could occur. Such extirpation is not likely to occur on a larger scale because open areas and reduced vegetation commonly exist in well-grazed pastures throughout the region.

Acknowledgments.-We thank the Nature Conservancy for providing Arapaho Prairie. Thanks to Ruth Ballinger for assisting with the manuscript. Gratitude is due to Jeff Bauermeister, Ellen Canney, Mike Davis, and Mark Vanek for field assistance. Kristin Watts was supported by a Howard Hughes Medical Institute undergraduate research fellowship.

\section{LITERATURE Cited}

BALLINGER, R. E. AND S. M. JonES. 1985. Ecological disturbance in a sandhills prairie: Impact and importance to the lizard community on Arapaho Prairie in western Nebraska. Prairie Nat., 17: 91-100.

- $\longrightarrow$ AND J. W. Nietfeldt. 1990. Patterns of resource use in a lizard community in the Nebraska sandhills prairie. Prairie Nat., 22:75-86.

- J. D. LYNCH AND P. H. Cole. 1979. Distribution and natural history of amphibians and reptiles in western Nebraska with ecological notes on the herpetiles of Arapaho Prairie. Prairie Nat., 11:65-74.

BlausteIn, A. R. AND D. B. WAKE. 1990. Declining amphibian populations: a new global phenomenon? Trends Ecol. Evol., 5:203-204.

BleEd, A. AND C. Flowerday (EDS.). 1989. An Atlas of the Sand Hills. Resource Atlas No. 5, Conserv. and Surv. Div., University of Nebraska-Lincoln, Lincoln. 238 p.

BRAGG, T. R. 1978. Effects of burning, cattle grazing, and topography on vegetation of the choppy sands range site in the Nebraska sandhills prairie. Proc. 1st Int. Rangeland Congr., p. 248253.

CAREY, C. 1993. Hypothesis concerning the causes of the disappearance of boreal toads from the mountains of Colorado. Conserv. Biol., 7:355-362.

Daubenmire, R. 1959. Plants and environment, 2nd ed. John Wiley and Sons, New York. 422 p.

FOLEY, P. 1994. Predicting extinction times from environmental stochasticity and carrying capacity. Conserv. Biol., 8:124-137.

Frissell, C. A. 1993. Topology of extinction and endangerment of native fishes in the Pacific northwest and California (U.S.A.). Conserv. Biol., 7:342-354.

JENNRICH, R. E. AND F. B. TURNER. 1969. Measurement of non-circular home range. J. Theor. Biol., 22: 227-237.

JOERn, A. 1982. Distributions, densities, and relative abundances of grasshoppers (Orthoptera: Acrididae) in a Nebraska sandhills prairie. Prairie Nat., 14:37-45.

JONES, S. M. AND D. L. DROGE. 1980. Home range size and spatial distributions of two sympatric lizard species (Sceloporus undulatus and Holbrookia maculata) in the sandhills of Nebraska. Herpetologica, 36:127-132.

KAUL, R. 1989. Plants, p. 127-142. In: A. Bleed and C. Flowerday (eds.). An atlas of the Sand Hills. Resource Atlas No. 5, Conserv. and Surv. Div., Univ. Nebraska-Lincoln, Lincoln.

KeEler, K. H., A. T. HARRision AND L. S. Vescio. 1980. Flora and sandhills prairie communities of Arapaho Prairie, Arthur County, Nebraska. Prairie Nat., 12:65-78.

LEVINS, R. 1970. Extinction, p. 77-107. In: M. Gerstenhaber (ed.). Lectures on mathematics in the life sciences, Vol. 2. American Mathematical Society, Providence, Rhode Island.

MacArthur, R. H. AND E. O. Wilson. 1967. The theory of island biogeography. Princeton University Press, Princeton, New Jersey. 203 p.

MiLler, S. M. 1989. Land development and use, p. 207-226. In: A. Bleed and C. Flowerday (eds.). An atlas of the Sand Hills. Resource Atlas No. 5, Conserv. and Surv. Div., University of NebraskaLincoln, Lincoln. 
StubBendieck, J. 1989. Range management, p. 227-237. In: A. Bleed and C. Flowerday (eds.). An atlas of the Sand Hills. Resource Atlas No. 5, Conserv. and Surv. Div., University of Nebraska-Lincoln, Lincoln.

Terborgh, J. AND B. Winter. 1980. Some causes of extinction, p. 119-133. In: M. E. Soulé and B. A Wilcox (eds.). Conservation biology, an evolutionary-ecological approach. Sinauer Associates, Sunderland, Massachusetts.

TinkLE, D. W. 1967. The life and demography of the side-blotched lizard, Uta stansburiana. Misc. Publ. Mus. Zool. Univ. Mich., 132:1-182.

WeAver, J. E. 1965. Native vegetation of Nebraska. University of Nebraska Press, Lincoln. 106 p.

Whitcomb, R. F., C. S. Robbins, J. F. Lynch, B. L. Whitcomb, K. KLimkiewicz And D. Bystrak. 1981. Effect of forest fragmentation of avifauna of the eastern deciduous forest, p. 125-206. In: $\mathrm{R}$. L. Burgess and D. M. Sharpe (eds.). Forest island dynamics in man-dominated landscapes, Springer-Verlag, New York.

ROYC E. BALLINGER AND KRISTIN S. WATTS, School of Biological Sciences, University of NebraskaLincoln, Lincoln 68588. Submitted 31 May 1994; accepted 10 May 1995 